\title{
THE IMPACT OF LAKE GERIO IRRIGATION SCHEME ON THE FARMING COMMUNITIES IN YOLA METROPOLITAN AREA
}

\author{
Ahmad, S. and Galtima, M. \\ Department of Geography, Modibbo Adama University of Technology, \\ Yola, Nigeria.
}

\begin{abstract}
This study assesses the impact of the Gerio irrigation scheme on the registered farming communities of Yola metropolitan area. Data for the study was obtained through a questionnaire survey administered randomly to 183 out of the total of 610 farmers that operated under the scheme. Personal interviews were also conducted with the officials of the scheme and other relevant agricultural development authorities in the area. The results show that the Gerio scheme has improved the income of the farming families, which reflected in the quality of their living conditions. A number of the farmers have now owned personal houses, means of transport and other basic possessions. The results further revealed that the people are highly susceptible to adoption of modern farming techniques such as the use of high yield seeds, application of fertilizers and pesticides. Other findings revealed that the majority of the farmers are willing to partner with the governmental agencies in the management of the Gerio scheme.
\end{abstract}

Keywords: Gerio, Farmers, Irrigation, Scheme, Farm, Grain, Vegetable.

\section{Introduction}

In Nigeria, large scale irrigation agriculture was introduced following the establishment of River Basin Development Authorities, between 1975 and 1980, to supplement and boost agricultural production. The objective was to curb food shortages experienced by the teeming population especially as result of the 1973 drought. Thus, the dry season farming (irrigation) was seen as an important method of combating the problems associated with erratic rainfall regimes particularly in the Northern parts of Nigeria and to eliminate the idleness or lag period between the seasonal rains. Agricultural products such as fresh vegetables (cabbage, lettuce, carrots, melons, onions and tomatoes), which are not farmed during the dry season and grains like maize, rice and wheat were all to be continuously produced through irrigation. It is stated that irrigated products have high percentage keeping quality as compared to those produced during the rainy season and the yield per unit area of irrigated crops are found to be much higher than those of rain fed crops (AERLS, 1978 and ADADP, 1996). This is perhaps what Bello, 1978 and El-Yakubu, 1978, have in mind by calling for the introduction of more irrigation schemes to supplement food production. Ever since a number of State and local Governments have continued to establish dams and other schemes in several localities across the country to boost dry season agriculture.

The Gerio irrigation project was established under the Upper Benue River Basin Authority (UBRBA) in 1977 to develop small scale irrigation through the extraction of water from Lake Gerio and the Benue River, and from bore holes. The objective was to contribute to national food security and to raise farmer's incomes in order to reduce the problem of poverty among the farming communities in the area. However, shortly after the implementation of the Gerio scheme myriads of problems emerged. These include the seasonal dryness of Lake and the loss of river volume, which causes long proximity 
of farms to water sources thereby increasing the over head cost of production and the shortage of implements to excavate water channel from the source (river/lake) to the pump intake. There is also the lack of effective pests control system, which often results into serious crop damage and reduction in yields. These problems notwithstanding it is believed that the Gerio scheme may have achieved some objectives. Therefore, the objective in this study is to assess the participating farmers' perspectives on the impact of the Gerio irrigation scheme in Yola metropolitan area. Thus, it is pertinent that this research work would attempt to provide answers to the following questions among others. Have the farmers' crop production increased per unit area? Is there any improvement in the income levels of the people? Are there any changes in the quality of life? Have the farmers benefited from any new farming skills? Can the farming communities sustain the scheme without further assistance from the government?

\section{THE STUDY AREA AND METHODOLOGY}

The Gerio irrigation project lies to the North-east of Metropolitan Yola, between latitude $9^{\circ} 14^{\prime \prime} \mathrm{N}$ and longitude $12^{\circ} 25^{\prime \prime} \mathrm{E}$, occupying an area of 850 hectares on an altitude of between 150 to 180 meters above sea level. The project is divided into phases I, II and III, (see figures 1 \& 2). The Phase II is subdivided into A, B and C, and further divided into plots of 0.25 ha to the participating farmers. Phases II, B and C, and III, B are the areas used for irrigation farming using the gravity method. While the phases II A \& III A are used for wet season farming and the phase I was used for sprinkler system of irrigation (over head irrigation), but now converted to wet season farming. The climate of Gerio Irrigation site corresponds to the climate of the Yola area, which is within the tropical climate marked by two alternating wet and dry seasons. The annual total rainfall is about $958.99 \mathrm{~mm}$, it begins usually in April and ends in October. The wettest months are August and September, while the dry season starts in late October and ends in March. The driest months are January and February. The relative Humidity is about $13 \%$ and the average annual temperature of about $39.7^{\circ}$ (Maximum) and $16^{\circ}$ (Minimum). Mean evaporation is about $9.5 \mathrm{~mm} / \mathrm{d}$. Highest evaporation is during the month with maximum mean temperature February, March, April and May. The lowest evaporation is from July to September when mean hours of bright sunshine are around 6 hours per day.

The registered participating farmers under the scheme (610 farmers), who are mostly from the Jimeta area of Metropolitan Yola, rely on the 320 ha of land provided by the scheme. The total population of Yola, 298, 240 (NPC, 2006), are also engaged in other economic activities such as trading, local craft, livestock rearing (intensive cattle, ram fattening and raising of poultry). Fishing in both the River Benue and Lake Gerio, also serve as one of the major occupations of the residence of the area. 


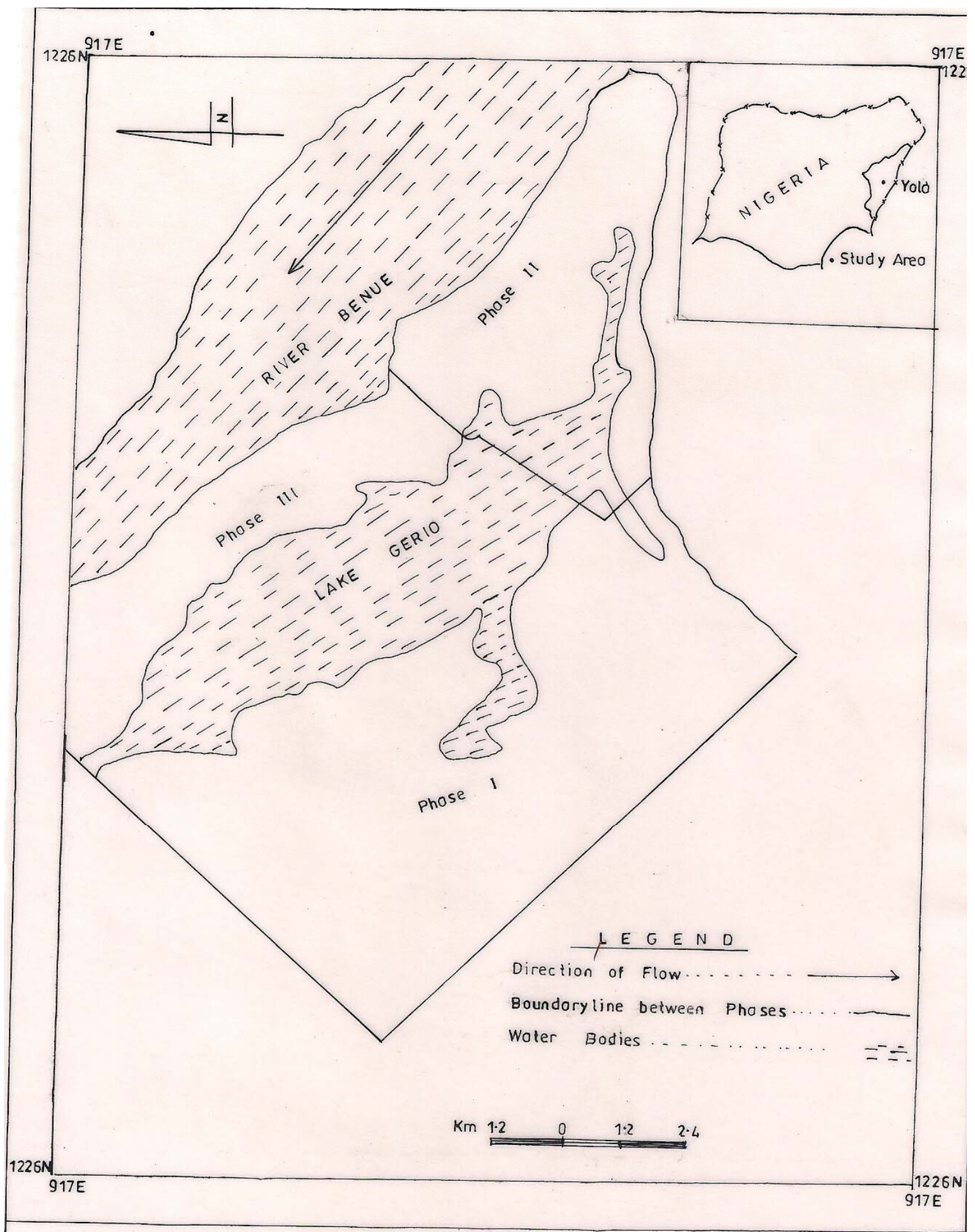

Figure 1: Map of the Gerio Irrigation Sites. 


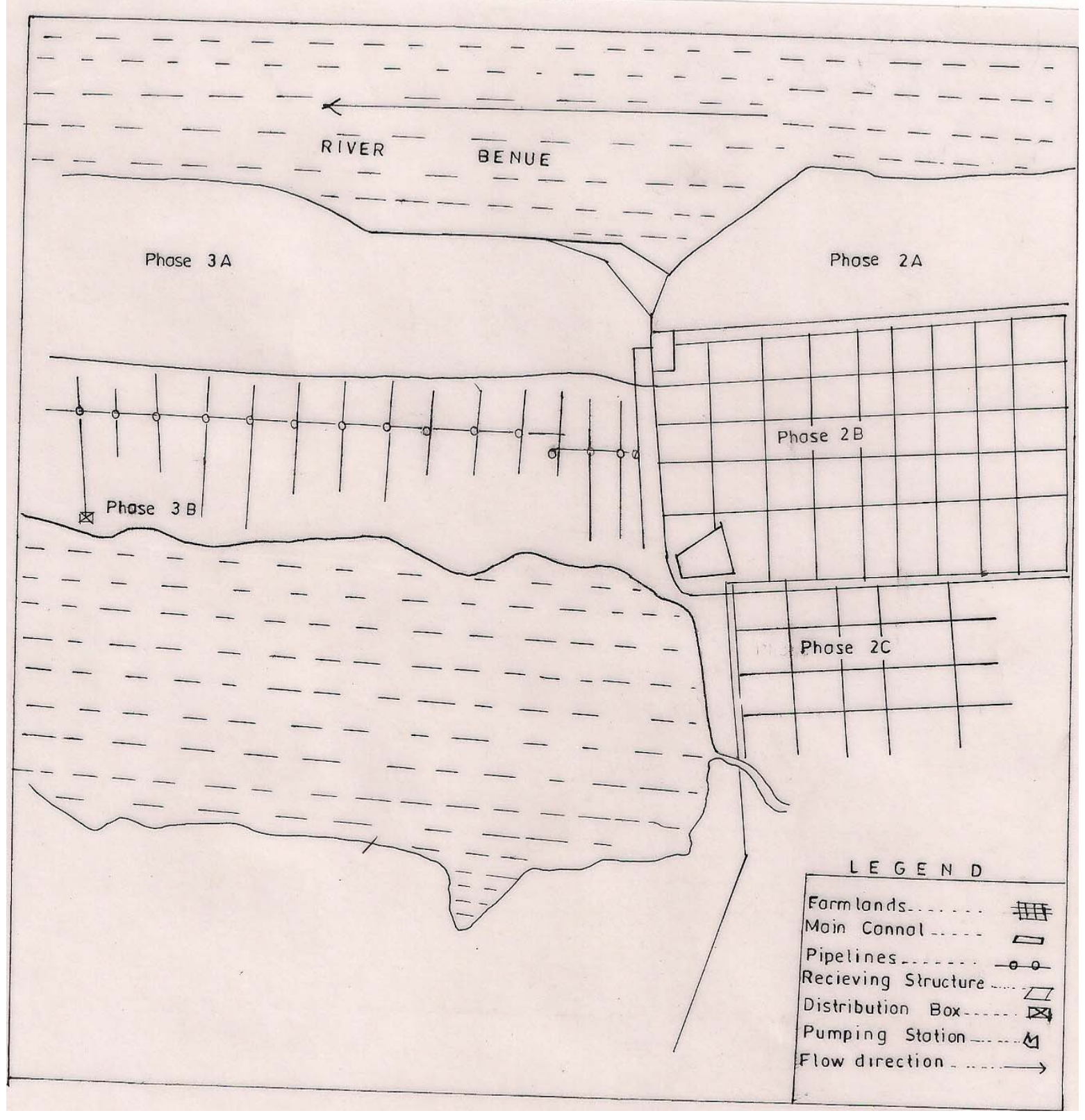

Figure 2: The Layout of the Gerio Irrigation Farming Plots.

Data for this study was obtained from two main sources, primary and secondary. The primary data was largely obtained through the use of a structured questionnaire administered to the farmers under the scheme. The Gerio Irrigation project has six hundred and ten (610) farmers in all, out of which Four Hundred and Sixty (460) are grain (rice and Maize) farmers, and One Hundred and Fifty (150) are vegetable farmers. A total of 183 farmers were selected through a simple random sampling method. The proportional allocation technique, $30 \%$ of the rice farmers and $30 \%$ of the vegetable farmers was used to draw the total sample for the research (138 grain farmers and 45 vegetable farmers). In selecting the sample size, a number was assigned to each name on the list of rice farmers and also to the list of vegetable farmers. The numbers were written on paper, squeezed and put in two different bags, each containing the numbers of rice farmers and those of the vegetable farmers. The numbers in each of the bags 
were manually picked, one number at a time and the name against each number picked is recorded, and the paper containing the number picked is folded again and dropped into the bag. This was repeatedly done until 138 samples were drawn from the rice farmers and 45 from the vegetable farmers. Thus, a total of 183 farmers were selected and the questionnaires were personally administered to all. However, only 165 questionnaires were found to be validly filled and accepted, while 18 were rejected as a result of some discrepancies in the responses. The data were analyzed using descriptive statistical methods and the presentation of the results in tabular forms.

\section{Results and Discussion}

\section{The socio-economic characteristics of the farmers}

The age distribution of the farmers as in table, 1, shows that most of the people are between the ages of 41 and 50 years old, representing $34.7 \%$ of the total and those aged between 31 and 40 accounted for $28.9 \%$. This reveals that majority of the farmers are in the peak of their productive life catering for the most dependent population, children and the old aged groups. About $91 \%$ of the people that are married have fairly large family sizes with an average of 6 children per family and are found to have multiple wives, which account for more than $66 \%$ of the total. In many communities of less developed countries the number of wives and children are often seen as major important workforce in agriculture. But, in the Gerio irrigation scheme hired labour is regarded as the major sources of farm workforce, where there is almost a gender balance. The women who made about $45 \%$ of the workforce are engaged in weeding, clearing, winnowing, tilling and harrowing.

Table 1: Age Distribution of the Gerio Farmers.

\begin{tabular}{|l|l|c|}
\hline Age & Distribution & Percentage \\
\hline $21-30$ & 11 & $6.8 \%$ \\
\hline $31-40$ & 48 & $28.9 \%$ \\
\hline $41-50$ & 57 & $34.7 \%$ \\
\hline $51-60$ & 25 & $15.3 \%$ \\
\hline $61-70$ & 16 & $9.4 \%$ \\
\hline 71 and above & 08 & $4.9 \%$ \\
\hline Total & 165 & $100.00 \%$ \\
\hline
\end{tabular}

Source: Field work, 2007.

In terms of farm ownership male farmers have $97.6 \%$, while the women participation is low, only about $2.4 \%$. This could be as a result of cultural restrictions, on muslim women who are discouraged by their faith. In table, 2, most of the Gerio farmers have formal education, which range from primary to tertiary types. Only 31.5 percent of the population attended Qur'anic school and it is believed that the level of understanding of issues by the people with Quranic education is more than those who do not have any form of education. This high number of educated people may have positive impact on farming practices in the area. 
Table 2: Educational Levels of the People.

\begin{tabular}{|l|l|l|}
\hline Education Type & Distribution & Percentage \\
\hline Informal (Qur'anic) & 52 & $31.5 \%$ \\
\hline Primary & 45 & $27.3 \%$ \\
\hline Secondary & 37 & $22.4 \%$ \\
\hline Tertiary & 31 & $18.8 \%$ \\
\hline Total & 165 & $100.00 \%$ \\
\hline
\end{tabular}

Source: Field Work, 2007.

The high number of educated persons suggests the examination of the occupational structure of the people. The analysis of the people's occupation revealed that $41.8 \%$ of the participants in the scheme are small-scale peasant farmers on full-time basis and do not engage in any other job activities. Thus, the majority of the people, about $58 \%$, are business men and/or traders, and civil servants who stated that they are all into farming to supplement their incomes. And they also indicated that their incomes have improved more than the pre-Gerio scheme period. In table, 3, the income distribution shows that most of the people, about $52 \%$ are found to live just above the absolute poverty level of USD \$2.0 per day to cater for their large families. And the remainder of the farmers $(48 \%)$ live above the poverty level with an average income of about USD\$5.00 per day, which is equivalent to N750.00 in the local currency. This has no doubt justified the quest for alternative source of income from farming especially for the civil servants and the like that required such incomes for the sustenance of their growing families.

Table 3: Annual Income Distribution of the People.

\begin{tabular}{|l|l|l|}
\hline Income Range & Distribution & Percentage $(\%)$ \\
\hline $50,000.00-150.000 .00$ & 42 & 25.5 \\
$151.000 .00-250,000.00$ & 45 & 27,2 \\
$251,000.00-350,000.00$ & 28 & 17.6 \\
$351,000.00-450,000.00$ & 21 & 12.8 \\
$451,000.00-550,000.00$ & 17 & 10.3 \\
$551,000.00$ above & 12 & 7.2 \\
\hline
\end{tabular}

Source: Field work, 2007.

\section{Quality of Life of the Farmers}

The survey revealed that most of the Gerio farming families stated that they have owned houses as result of the improved incomes realized from the scheme. About $76.4 \%$ of the people owned houses, while $23.6 \%$ live in rented quarters. This implies that the farmers not only produce for the sustenance of their families, but also save the proceeds for material possession. This is further buttressed in table, 4, which indicated the ownership of means of transport among the people.

Table 4: Ownership of Means of Transport

\begin{tabular}{|l|l|l|}
\hline Type of Transport & Distribution & Percentage \\
\hline Bicycle & 49 & $29.7 \%$ \\
\hline Motorcycle & 37 & $22.4 \%$ \\
\hline Car & 25 & $15.1 \%$ \\
\hline Pick-up Van & 06 & $3.6 \%$ \\
\hline Total & 117 & $70.8 \%$ \\
\hline
\end{tabular}

Source: Field work, 2007. 
The transport ownership analysis shows that about $70.8 \%$ of the farmers claimed to have owned vehicles after engaging in the Gerio scheme. The high level of vehicle and motorcycle ownership really suggests the increment in the purchasing power of the people amidst other commitments. Related to the income factor is the ability of the farming families in paying school fees for their children. About $78.8 \%$ of the people pay school fees, which range between N1,500.00 - N4,000.00 per term. Hitherto, the children were educated in free public schools. Thus, the improved incomes encouraged the attendance of relatively better quality private and public schools. Those that do not pay any fees $(21.2 \%)$ either have no children and/or whose children have completed schools.

\section{The Impact of the Gerio Scheme on Farm Practice}

\section{(a) Types of Crops Produced}

The farm size per farmer in the Gerio scheme is determined by the project officials, unlike farming outside the project areas. The official plot size is $0.25 \mathrm{ha}$, but in the areas of land reclamation and flood recedes the farmers on their own have taken the advantage and added extra areas for farming, thus causing variation in farm sizes. About $79.8 \%$ of the people had the official allocation of 0.25 ha plot, $9.7 \%$ had 0.3 ha, $4.8 \%$ had 0.4 ha, while $5.7 \%$ had 0.5 ha plot and about $1.0 \%$ of the farmers have plots of 0.6 ha. It was revealed that the financial capabilities and the types of crops grown by the farmers accounted for the extra land holdings. However, most of these farmers, about $73.9 \%$, depend on the use of irrigation pumps provided by the Upper Benue River Basin Authority especially in rice cultivation. The other farmers rely on petroleum driven pumps predominantly in the cultivation of the vegetables, which require less water and therefore cheaper to use for such crops than on the production of grains like rice.

However, the analysis of the farming experience indicate that before the establishment of the Gerio scheme the people are found to have an average of 7 years of farming experience. This is suggestive of the fact that most of the people joined farming as a result of the scheme. The establishment of the scheme has increased the farming experience/skills, about $74 \%$ of the population now have an average of 15 years of farming experience. The analysis further shows that about $30.4 \%$ of the farmers have combined the dry and raining seasons farming. They stated that the dry season farming encouraged them to enter the rain-fed agricultural practice.

The farming outputs are found to be influenced by a number of factors. These include differences in the location of the plots (areas of short and prolonged floods), quantity of the fertilizer application, adoption of new techniques and introduction of high yield varieties among others. All the farmers who were practicing in the area before the scheme attested to having increased outputs as a result of the establishment of the scheme. However, the outputs differ even among the majority $(79.8 \%)$, who hold the official allocation of 0.25 ha plot per person. This is mostly found to be dependent on the differences in the management skills especially in fertilizer application and introduction of new skills. The variation in the yields particularly for the grains per 0.25 ha of plot shows that about $10.5 \%$ of the farmers have between $6-10$ bags, $26.1 \%$ recorded between 11-15 bags, while $51.3 \%$ had $16-20$ bags, and $12.1 \%$ got 21-25 bags per 0.25 ha plot. The older farmers stated that these yields $(0.25$ ha per plot $)$ through irrigation are much higher than what is obtained under rain fed farming in or outside 
the scheme area. This confirms the assertion that irrigation output per unit area is higher than rain-fed agricultural production (AERLS, 1978 and Singh, 1990).

However, the principal crops grown in the Gerio irrigation scheme are vegetable, rice and Maize, which are well suited for the soils and the general growing conditions, and also because they are the staple food crops in the area. The farmers adduced various reasons for their choice of the crops produced. The vegetable is the most dominant crop produced as a result of its' relative shorter cultivation periods and the quick monetary returns from the markets. All the participating farmers reported high returns in vegetable production over those of the grains. They further stated that the time taken for one cropping season of rice is equivalent to three seasons of vegetable production. Thus, this multiplicity of production gave the vegetable an added advantage over grain production (rice and maize). Some farmers are of the view that they cultivate rice because vegetable farming is laborious and the marketing is often tedious due to the risk of perishing. A few of the farmers about $18 \%$ are engaged in mixed cropping of maize and rice, on one hand and rice and vegetable on the other, all producing for subsistence and the market.

Before joining the Gerio scheme, the respondents do not attached any importance to seeds selection for cultivation and were not able to differentiate the variety of seeds. But, with the inception of the scheme the farmers have realized through the extension services offered, the importance of seeds selection, which determines to a lager extent farm outputs. The farmers used different varieties of rice such as the IITA-306, IITA-212 and numerous other Chinese varieties such as Faro 44. The varieties are planted based on the need of the farmer and the location of his/her plot. About $13.9 \%$ of the farmers in the scheme used ITA-306, 34.5\% are dependent on ITA-212, while $40.1 \%$ and $11.5 \%$ use Faro 44 and other Chinese varieties respectively. However, the farmers stated that they are faced with the problems of pests and diseases in the course of production. The supplies of pesticides are no longer made by the Adamawa Agricultural Development Program (ADADP) and therefore rely on the open market. The scheme has also broadened the skills of fertilizer use and application, which increased more than two fold. This could be as a result of the educational levels of the people and the availability of subsidized fertilizers from the government organizations like the ADADP and the UBRBDA.

\section{(b) Farming Subsidies}

The found that about $70 \%$ of the farmers have received some form of assistance from the Gerio authorities. The forms of the assistance include water pumps $(26.3 \%)$ and improved seed variety (54.4\%) loans, while $19.3 \%$ of the people combined the two loans. The farmers were asked if they could completely take-over the management of the scheme and provide all the necessary services, their response was overwhelmingly negative. About $98.1 \%$ did not agree that the farmers can manage the scheme effectively because of huge financial requirements and the lack of cooperation among each other. This view corresponds with Olu, (2001), who stated that government has to continue to provide necessary capital in the development of infrastructure, since the farmers whether individually or collectively as organization are too poor to provide the needed funds. And neither the financial institutions are likely to provide capital for irrigated agricultural facilities. However, more than $57 \%$ of the farmers are of the view that the scheme could be managed as a joint venture program with the government agencies. 


\section{Conclusion}

The Gerio irrigation scheme has impacted positively on the lives of the participating farming communities of Yola metropolitan area. It has improved the incomes of the farmers and subsequently their quality of life. The scheme has continued to attract people into the farming business and have increased farming skills of the people. Thus, leading to increased food production, such that the people are now dependent on the scheme for more than $95 \%$ of dry season production and supplies of vegetables and Maize in the Yola area. It is therefore suggested that the government through its' agencies should establish similar projects along the Benue valley and other river basins not only for the production of food, but also as a strategy for alleviating poverty among the teeming population in the country. Partnership arrangements between the government and farmer's associations under such irrigation schemes should also be explored for the sustenance of the existing projects and to divest government control.

\section{References}

Adamawa Agricultural Development Project (ADADP), (1996): Annual Report.

Agricultural Extension Research \& Liaison Services (AERLS), (1978): Guide to Production of Pepper, Cabbage, Carrot etc. Institute of Agricultural Research, Samaru, Ahmadu Bello University, Zaria, Guide No. 43.

Bello, S., (1978): Aftermath of the 1972-74 Drought in Nigeria, A Research Report. Federal Department of Water Resources and Nigeria Institute of Social and Economic Research, Ahmadu Bello University, Zaria.

El-Yakubu, I., (1978): Aftermath of the 1972-74 Drought in Nigeria, A Research Report. Federal Department of Water Resources and Nigeria Institute of Social and Economic Research, Ahmadu Bello University, Zaria.

National Population Commission (NPC), (2006): Nigeria Population Census.

Olu, A., (2001): An Over view of Organization and Management of Public Irrigation Scheme. Proceedings of a National Workshop, NAERLS, Ahmadu Bello University, Zaria.

Singh, D.V., (1990): Production and Marketing of Off-Season Vegetable. Mita Publishers Limited, New Delhi, 11059, India.

Mubi, A.M., Tukur, A.L. \& Bashir, B.A., (2005): Sustainable River Basin Management In Nigeria, A Case Study of the Upper Benue River Basin Development Authority, Journal of Environmental Sciences, Volume 9, No. 1.

Team Planning International, (1992): Studies in Yola Irrigation Project. Aqua Consult Engineering, Lagos, Volume 1.

Upper Benue River Basin Development Authority (UBRBDA), (1977): Gerio Reclamation Project - Final Report, Yola, Nigeria. 